Review

\title{
The Effectiveness of Spiritual Psychotherapy on Patients with Mental Disorders: A Systematic Review
}

\author{
Ahmad Wahyudi*1, Ah Yusuf ${ }^{1}$, Mundakir ${ }^{2}$ \\ ${ }^{1}$ Faculty of Nursing, Universitas Airlangga, Surabaya, Indonesia \\ ${ }^{2}$ Faculty of Health Sciences, Universitas Muhammadiyah, Surabaya, Indonesia
}

(*ah-yusuf@fkp.unair.ac.id)

\begin{abstract}
This article aimed to examine the effectiveness of handling mental-based mental disorders from various studies that have been conducted. The articles used in this systematic review were searched in the SCOPUS, PROQUEST, SPRINGERLINK, SAGE and SCIENCEDIRECT databases which is published between 2016-2020. The keyword used were "mental disorders" or "mental illness" and "spiritual" or "religious", with the use of the phrase Boolean Operators. The articles selected according to the inclusion criteria include articles stating the effectiveness of spiritual healing for mental disorders, articles that analyzed mental illness patients in RCT, case-control studies and experiment. The articles obtained then were analyzed with the DSVIA conclusion table (design, sampling, variables, intervention and analysis). There were 15 articles that meet the criteria as a systematic review. The study result showed that there was a relationship between religious/spiritual involvement and mental disorders (positive). The findings from previous research indicated that religion play an important role in many situations because religious beliefs and rules affect people's lives. The majority of the previous literature stated a significant relationship between religious beliefs and practices and mental health.
\end{abstract}

Key words: Mental disorder, religious belief, spiritualism

https://doi.org/10.33860/jik.v15i1.436

(C) 2021 by the authors. Submitted for possible open access publication under the terms and conditions of the Creative Commons Attribution (CC BY SA) license (https://creativecommons.org/licenses/by-sa/4.0/).

\section{INTRODUCTION}

Currently, mental disorders are important problem in the world health sector. The high incidence of mental disorders and increase in each period makes it challenging for health workers to do many things in mental disorders and experiencing it ${ }^{1}$. Mental disorders are clinical signs of deviations in one's thinking, feelings and attitudes or behavior ${ }^{2}$. Mental disorders occur because of the unfulfilled needs of a person's soul. A person experiences dissatisfaction which then results in negative feelings such as disappointment, shame, and a special degree causing feelings of low self-esteem ${ }^{3}$.

The number of people with mental disorders in the world reaches 450 million, with an estimated $75 \%$ in countries with low income. However, individuals who expect the high level of social equality and could not meet the demands will experience stress, anxiety and depression until they finally experience real mental disorders ${ }^{1}$. There are about 35 million people affected by depression, 60 million people have bipolar disorder, 21 million have schizophrenia, and 47.5 million are affected by dementia. The various biological, psychological and social factors population diversity in Indonesia lead the number of cases of mental disorders continues to increase, increasing the burden on the state and decreasing human productivity for the long term ${ }^{4}$. A person who experiences mental disorders has unstable emotions and erratic mental status at any time and tends to experience a decline if not handled properly ${ }^{5}$.

The spiritual role is needed in improving one's mental condition because basically, someone who experiences mental disorders begins from the inability to think positively and give up on the situation ${ }^{6}$. The practice of spirituality in everyday life becomes 
the main asset for individuals to face life situations that have many demands ${ }^{7}$. This situation encouraging many hospitals, mental rehabilitation centers and mental health services apply spiritual concepts in overcoming mental disorders using spiritual motivation methods, spiritual practice and services based on religious principles ${ }^{8}$.

This study aimed to determine the application of spiritual healing to patients with mental disorders, and patients with depression. Previous studies have been discussed about the relationship of spiritual healing to the treatment of mental disorders, but this systematic review study discussed more specifically on how spiritual healing improves the condition of patients with mental disorders, and described the types of spiritual healing that have high authority in treating mental disorders.

\section{METHOD}

The literature search was carried out in several databases such as SCOPUS, SAGE, PROQUES, SCIENTDIRECT and SPRINKLINK. The search strategy for journals or articles is performed using theme terms with medical subject headings (MeSH) combined with Boolean operators. The keywords used in the search were "mental disorders" OR "mental illness" AND "spiritual" OR "religion" from 2016 to 2020.

\section{Data Selection / Study}

The data were assessed for feasibility using the PICOT framework (Population, Intervention, Comparation, Outcome, Time). The inclusion criteria were (1) patients with mental disorders (2) over 30 years of age, both male and female (3) patients in controlled conditions (4) type of research: randomized controlled trials (RCT), casecontrol studies, quasi-experimental and actual experimental (5) type of intervention: provision of spiritual healing and measurement of mental disorders (6) Main result: an article that discusses the effectiveness of spiritual therapy in the management of patients with mental, both as complementary and primary therapy.

\section{Data Quality Assessment}

A total of 2,712 journals were found. The search results were from five databases that Scopus as many as 721 articles, Sage as many as 83 articles, ProQuest as many as 825 articles, Science direct as many as
328 articles and Springer-link as many as 755 articles. Of the 2,712 articles found, 15 journals/articles were selected according to the inclusion criteria, both types of population, intervention, comparison, results and year of publication. As for details of the journal identification and selection process can be seen in Figure 1:a flow diagram adapted from preferred reporting terms for systematic reviews (PRISMA) at the design stage ${ }^{9}$.

\section{RESULTS}

The articles analyzed in this systematic review are 15 articles that fit the predetermined inclusion criteria. The articles derived from Israel, Japan, Poland, Australia, London, America, China and India. The number of respondents were varied between 157041. The research design used in the article was 3 articles with a qualitative design, 4 articles with a Randomized controlled trial (RCT) design, 3 articles with a cross sectional design and 3 articles with an observational/survey design, and 3 articles with an experimental design. From 15 articles found that there are many methods and forms of therapy used, namely strengthening spiritual motivation and therapy to implement spiritual practice (worship).

Various studies of 15 articles were obtained express opinions and findings of the same on the effectiveness of spiritual therapies against mental disorders. The average score of anxiety in group 2 after spiritual therapy intervention is significantly lower ( $\mathrm{P}$ $<0.05)$. which means that the combination spiritual and drug therapy is effective in reducing anxiety. The patients become more obedient to the officers direction, think more positively and do not easily give up 5. Another result also states that the correct spiritual practice makes patients feel comfort, sincerity, strength, happiness, and hope. The feeling of serenity make a positive value in reducing the symptoms of mental disorders ${ }^{8}$, as reinforcements of articles results similarity, found there is a significant decrease $(\mathrm{p}=0.001$ ) in the score of anxiety and muscle tension ( $\mathrm{p}=$ $0.011)$, and the increase in well-being ( $\mathrm{p}=$ 0.003). This means that treating depressed patients using a spiritual approach makes them stronger in facing illness and more positive in seeing lives ${ }^{10}$.

The following is a systematic explanation of the search results for the articles used in this 
study in table 1.
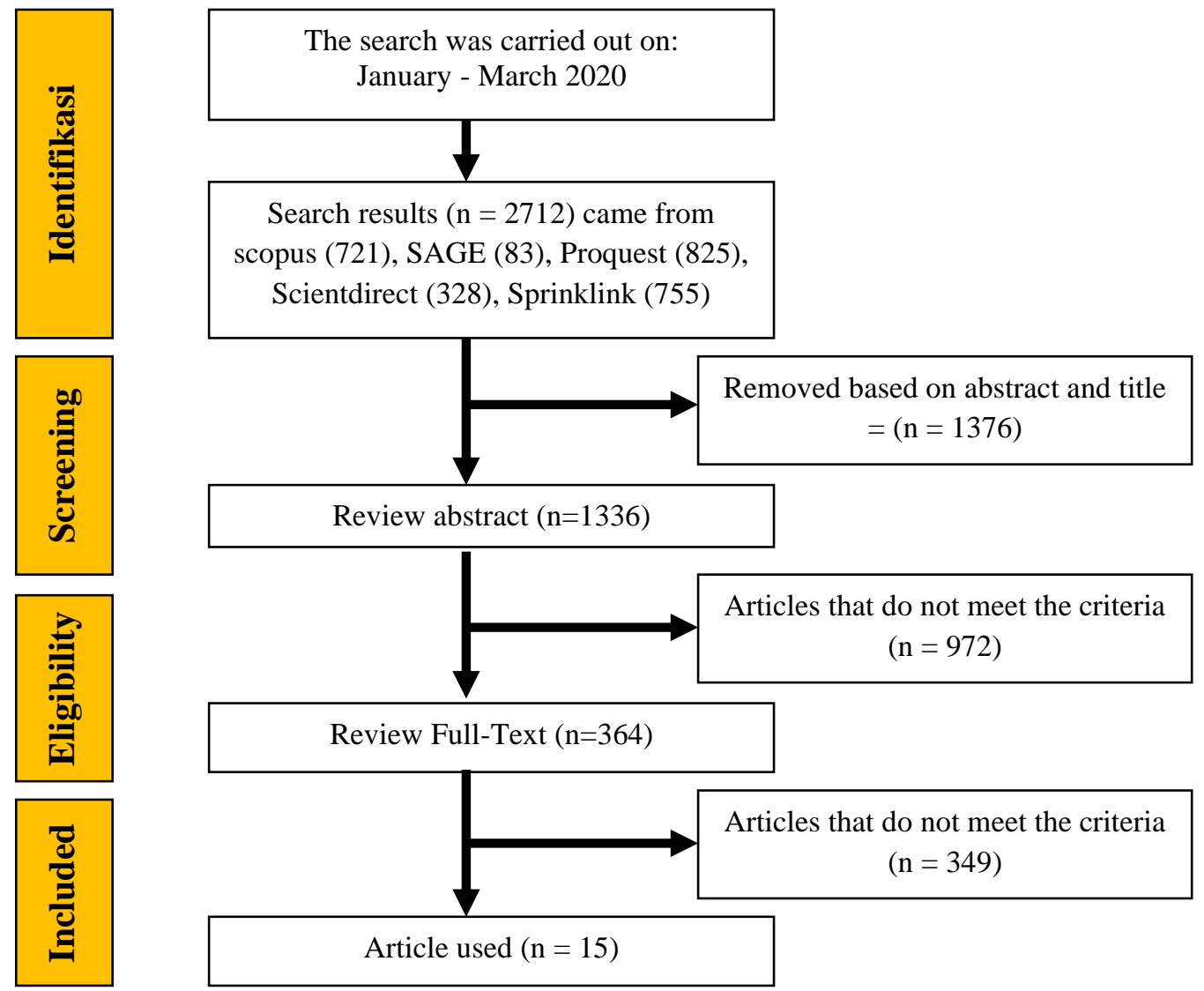

Figure 1: PRISMA flow chart of systematic review article selection

Table 1. Journals Based on Inclusion Criteria

\begin{tabular}{|c|c|c|c|c|c|}
\hline $\begin{array}{c}\text { First } \\
\text { author }\end{array}$ & Title & Design & Sample & Intervention & Result \\
\hline $\begin{array}{l}\text { Chida } \\
\text { Y, et al } \\
(2016)\end{array}$ & $\begin{array}{l}\text { A Novel Religious } \\
\text { / Spiritual Group } \\
\text { Psychotherapy } \\
\text { Reduces } \\
\text { Depressive } \\
\text { Symptoms in a } \\
\text { Randomized } \\
\text { Clinical }\end{array}$ & $\begin{array}{l}\text { Randomi } \\
\text { zed } \\
\text { Controlle } \\
d \text { Trial } \\
\text { (RCT) }\end{array}$ & $\begin{array}{l}118 \\
\text { depression } \\
\text { patients } \\
\text { were } \\
\text { divided } \\
\text { into two } \\
\text { groups, } \\
\text { namely the } \\
\text { treatment } \\
\text { group (n = } \\
\text { 58) and the } \\
\text { control } \\
\text { group (n = } \\
60)\end{array}$ & $\begin{array}{l}\text { The intervention } \\
\text { model of the } \\
\text { group " 'Happy } \\
\text { Smile Clinic } \\
\text { (HSC) " which } \\
\text { was carried out for } \\
5 \text { weeks (90 } \\
\text { minutes/week) } \\
\text { which } \\
\text { a symptom } \\
\text { orientation from a } \\
\text { spiritual } \\
\text { perspective of life }\end{array}$ & $\begin{array}{l}\text { Group psychotherapy } \\
\text { spiritual" HSC" This reduces } \\
\text { the symptoms of depression } \\
\text { in outpatients diagnosed with } \\
\text { the disorder Japanese feeling, } \\
\text { neurotic disorders associated } \\
\text { with stress and somatoform, } \\
\text { or an eating disorder and } \\
\text { other psychological disorders. }\end{array}$ \\
\hline $\begin{array}{l}\text { Nikfarj } \\
\text { am M, } \\
\text { et al, } \\
(2018)\end{array}$ & $\begin{array}{l}\text { Effect of } \text { Group } \\
\text { Religious } \\
\text { Intervention on } \\
\text { Spiritual Health } \\
\text { and Reduction of } \\
\text { Symptoms in } \\
\text { Patients } \\
\text { Anxiety }\end{array}$ & $\begin{array}{l}\text { Experime } \\
n t\end{array}$ & $\begin{array}{l}72 \text { anxiety } \\
\text { patients. }\end{array}$ & $\begin{array}{l}\text { Respondents were } \\
\text { divided into } 2 \\
\text { large groups, } \\
\text { namely group 1 } \\
\text { was only given } \\
\text { drug therapy and } \\
\text { group } 2 \text { was } \\
\text { given drug therap } \\
\text { y and spiritual }\end{array}$ & $\begin{array}{l}\text { The mean score } \\
\text { of anxiety level in group } \\
2 \text { after the intervention was } \\
\text { significantly lower } \\
<0.05 \text { ). which means that } \\
\text { the combination spiritual } \\
\text { therapy of drug therapy is } \\
\text { very effective in reducing the } \\
\text { level of anxiety so that }\end{array}$ \\
\hline
\end{tabular}




\begin{tabular}{|c|c|c|c|c|c|}
\hline $\begin{array}{c}\text { First } \\
\text { author }\end{array}$ & Title & Design & Sample & Intervention & Result \\
\hline & & & & $\begin{array}{l}\text { approach which } \\
\text { was carried out for } \\
3 \text { weeks with } \\
\text { duration of } 90 \\
\text { minutes divided } \\
\text { into } 5 \text { sessions. }\end{array}$ & $\begin{array}{l}\text { patients are more obedient to } \\
\text { the direction of the officer and } \\
\text { are more positive thinking and } \\
\text { do not easily give up }\end{array}$ \\
\hline $\begin{array}{l}\text { Jones } \\
\text { S, et } a, l \\
(2018) \\
8\end{array}$ & $\begin{array}{l}\text { Concepts, } \\
\text { Practices and } \\
\text { Advantages of } \\
\text { Spirituality } \\
\text { Among People } \\
\text { with a Chronic } \\
\text { Mental Illness in } \\
\text { Melbourne }\end{array}$ & $\begin{array}{l}\text { Qualitati } \\
\text { ve } \\
\text { descripti } \\
\text { on }\end{array}$ & $\begin{array}{l}16 \\
\text { Australian } \\
\text { participant } \\
\text { s who have } \\
\text { experience } \\
\text { d severe } \\
\text { mental } \\
\text { disorders }\end{array}$ & $\begin{array}{l}\text { Conducting a } \\
\text { structured } \\
\text { interview and seek } \\
\text { healing factor } \\
\text { participant from } \\
\text { severe mental } \\
\text { illness who are } \\
\text { focused on their } \\
\text { relation to } \\
\text { spiritual practices } \\
\text { such as (belief, } \\
\text { pray and closeness } \\
\text { to God) }\end{array}$ & $\begin{array}{l}\text { The findings suggest that } \\
\text { correct spiritual practice that } \\
\text { is } \\
\text { makes patients feel comfort, } \\
\text { sincerity, strength, happiness, } \\
\text { hope. So that it makes } \\
\text { thinking calm and makes it } \\
\text { one of the positive values in } \\
\text { reducing the symptoms of } \\
\text { mental disorders. }\end{array}$ \\
\hline $\begin{array}{l}\text { Sankhe } \\
\text { A, et } \\
a l \\
(2017) \\
12\end{array}$ & $\begin{array}{l}\text { Evaluation of the } \\
\text { effect of Spiritual } \\
\text { care on patients } \\
\text { with generalized } \\
\text { anxiety and } \\
\text { depression: A } \\
\text { Randomized } \\
\text { Controlled Study }\end{array}$ & $\begin{array}{l}\text { Randomi } \\
\text { zed } \\
\text { Controlle } \\
d \text { Trial } \\
(\mathrm{RCT})\end{array}$ & $\begin{array}{l}\text { A total of } \\
110 \\
\text { participant } \\
\mathrm{S} \\
\text { Who is } \\
\text { experienci } \\
\text { ng generali } \\
\text { zed anxiety } \\
\text { or mild to } \\
\text { moderate } \\
\text { depression } \\
\text { based } \\
\text { on (DSM- } \\
\text { 5) }\end{array}$ & $\begin{array}{l}\text { Spiritual healing } \\
\text { was carried out in } \\
\text { the control group } \\
\text { for } 6 \text { weeks such } \\
\text { as spiritual } \\
\text { guidance, } \\
\text { strengthening of } \\
\text { faith, fortitude and } \\
\text { learning to accept } \\
\text { a situation } \\
\text { positively. }\end{array}$ & $\begin{array}{l}\text { The results showed a } \\
\text { significant increase in the } \\
\text { mental health of patients who } \\
\text { were given spiritual healing } \\
\text { so that it could be said to be } \\
\text { effective in reducing levels of } \\
\text { anxiety and depression. }\end{array}$ \\
\hline $\begin{array}{l}\text { Silva J, } \\
\text { M A, et } \\
\text { al, } \\
(2017) \\
\\
13\end{array}$ & $\begin{array}{l}\text { Perceived } \\
\text { Spirituality, } \\
\text { Mindfulness and } \\
\text { Quality of Life in } \\
\text { Psychiatric } \\
\text { Patients }\end{array}$ & $\begin{array}{l}\text { Annalisa } \\
\text { survey }\end{array}$ & $\begin{array}{l}96 \text { patients } \\
\text { were } \\
\text { selected } \\
\text { from the } \\
\text { Hospital an } \\
\text { d Psychoso } \\
\text { cial Specia } \\
\text { lized Reha } \\
\text { bilitation } \\
\text { Service } \\
\end{array}$ & $\begin{array}{l}\text { Give full attention } \\
\text { to patients with a } \\
\text { spiritual approach } \\
\text { by medical } \\
\text { personnel and } \\
\text { nurses on duty } \\
\text { during patient } \\
\text { care. }\end{array}$ & $\begin{array}{l}\text { There is a positive } \\
\text { relationship between treating } \\
\text { people with mental health } \\
\text { condition with a spiritual } \\
\text { approach to improving the } \\
\text { patient's condition to improve } \\
\text { the quality of life and self- } \\
\text { belief. }\end{array}$ \\
\hline $\begin{array}{c}\text { Serfaty } \\
\text { DR, et } \\
a l, \\
(2020)\end{array}$ & $\begin{array}{l}\text { How are psychotic } \\
\text { symptoms and } \\
\text { treatment factors } \\
\text { affected by } \\
\text { religion? A cross- } \\
\text { sectional study } \\
\text { about religious } \\
\text { coping among } \\
\text { ultra-Orthodox } \\
\text { Jews }\end{array}$ & $\begin{array}{l}\text { cross- } \\
\text { sectional } \\
\text { study }\end{array}$ & $\begin{array}{lr}15 \quad \text { male } \\
\text { and } 15 \\
\text { females }\end{array}$ & $\begin{array}{l}\text { Giving } \\
\text { questionnaires to } \\
\text { respondents } \\
\text { related to the } \\
\text { spiritual level of } \\
\text { individuals who } \\
\text { are believed and } \\
\text { practiced every } \\
\text { day. }\end{array}$ & $\begin{array}{l}\text { The results showed that } \\
\text { religious factors can increase } \\
\text { motivation and moral support } \\
\text { in treatment. } \\
\text { positive religious coping was } \\
\text { associated with increased } \\
\text { treatment expectations and a } \\
\text { better quality of life; and } \\
\text { belief in God was associated } \\
\text { with } \\
\text { reduced psychiatric symptom } \\
\text { s and greater hope for } \\
\text { treatment }\end{array}$ \\
\hline $\begin{array}{l}\text { Mara } \\
\text { É, et al, }\end{array}$ & $\begin{array}{l}\text { Complementary } \\
\text { Therapies in }\end{array}$ & $R C T$ & $\begin{array}{l}41 \text { patients } \\
\text { with }\end{array}$ & $\begin{array}{l}\text { Respondents were } \\
\text { put in a special }\end{array}$ & $\begin{array}{l}\text { There is a decrease } \\
\text { in the significant }(\mathrm{p}=0.001)\end{array}$ \\
\hline
\end{tabular}




\begin{tabular}{|c|c|c|c|c|c|}
\hline $\begin{array}{c}\text { First } \\
\text { author }\end{array}$ & Title & Design & Sample & Intervention & Result \\
\hline$(2016)$ & $\begin{array}{l}\text { Medicine } \\
\text { Effectiveness of } \\
\text { Spirits "passé ", } \\
\text { (Spiritual healing) } \\
\text { for anxiety levels, } \\
\text { depression, pain, } \\
\text { muscle tension, } \\
\text { well-being, and } \\
\text { physiological } \\
\text { parameters in } \\
\text { cardiovascular } \\
\text { inpatients } \\
\end{array}$ & & $\begin{array}{l}\text { depression } \\
\text { severe } \\
\text { disease } \\
\text { cardiovasc } \\
\text { ular }\end{array}$ & $\begin{array}{l}\text { room and were } \\
\text { given spiritual } \\
\text { motivation and } \\
\text { asked to pray to } \\
\text { God for his } \\
\text { prayer. This was } \\
\text { done for } 3 \\
\text { consecutive days } \\
\text { with duration of } \\
10 \text { minutes per } \\
\text { session. }\end{array}$ & $\begin{array}{l}\text { in the muscle tension and } \\
\text { anxiety scores }(\mathrm{p}=0.011) \text {, } \\
\text { increased welfare (p }= \\
0.003) \text {. This means that } \\
\text { treating depressed patients } \\
\text { using a spiritual approach } \\
\text { makes the patient stronger in } \\
\text { facing their illness and more } \\
\text { positive in seeing their life. }\end{array}$ \\
\hline $\begin{array}{l}\text { Harris } \\
\text { JI, et } \\
a l, \\
(2018) \\
\\
15\end{array}$ & $\begin{array}{l}\text { Spiritually } \\
\text { integrated care } \\
\text { for PTSD: A } \\
\text { randomized } \\
\text { controlled trial of } \\
\text { "Building } \\
\text { Spiritual } \\
\text { Strength" }\end{array}$ & $R C T$ & & $\begin{array}{l}\text { Religious leaders } \\
\text { gave a spiritual } \\
\text { enlighten } \\
\text { intervention for } 2 \\
\text { consecutive } \\
\text { months. }\end{array}$ & $\begin{array}{l}\text { The study result obtained } \\
\text { satisfactory results on the } \\
\text { impact of exposure and } \\
\text { motivation of patients } \\
\text { with spiritual, religious and } \\
\text { divine approaches, which } \\
\text { made trauma and feelings of } \\
\text { low self-esteem reduced and } \\
\text { increased self-confidence, } \\
\text { enthusiasm and positive } \\
\text { thinking. }\end{array}$ \\
\hline $\begin{array}{c}\text { Sithey } \\
\text { G, et } \\
a l \\
(2015) \\
1\end{array}$ & 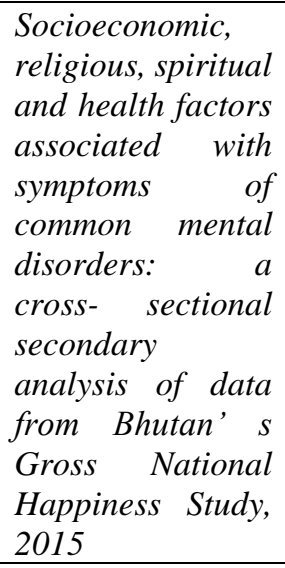 & $\begin{array}{l}\text { Survey } \\
\text { Annalisa }\end{array}$ & $\begin{array}{l}7041 \\
\text { respondent } \\
s\end{array}$ & $\begin{array}{l}\text { Giving } \\
\text { questionnaires } \\
\text { on socio- } \\
\text { economic, } \\
\text { religious, spiritual } \\
\text { and health factors } \\
\text { related to mental } \\
\text { disorders. }\end{array}$ & $\begin{array}{l}\text { The findings in this study } \\
\text { state that the impact of } \\
\text { religion and spirituality on } \\
\text { mental disorders is vital. } \\
\text { People who have strong } \\
\text { religious and belief will be } \\
\text { less likely to be diagnosed } \\
\text { with mental illness. So that } \\
\text { spirituality becomes the } \\
\text { foundation of Bhutanese } \\
\text { society is anticipating } \\
\text { psychological disorders by } \\
\text { thinking positively. }\end{array}$ \\
\hline $\begin{array}{c}\text { Rosyan } \\
\text { ti L, et } \\
a l, \\
(2019) \\
16\end{array}$ & $\begin{array}{l}\text { Change of Brief } \\
\text { Psychiatric Rating } \\
\text { Scaler (BPRS) } \\
\text { Valuer with } \\
\text { Spiritual Qur'an } \\
\text { Emotionalr } \\
\text { Freedom } \\
\text { Techniquer } \\
\text { (SQEFT) Therapy } \\
\text { on Mental } \\
\text { Disorder Patient } \\
\end{array}$ & $\begin{array}{l}\text { Quasy } \\
\text { eksperim } \\
\text { ent }\end{array}$ & $\begin{array}{l}20 \\
\text { participant } \\
s\end{array}$ & $\begin{array}{l}\text { Administration } \\
\text { of SQEFT } \\
\text { therapy interventi } \\
\text { on }\end{array}$ & $\begin{array}{l}\text { Therapy (SQEFT) has been } \\
\text { shown to help cure } \\
\text { schizophrenic patients as } \\
\text { a trap therapy that } \\
\text { practical, affordable, and } \\
\text { without side effects, and can } \\
\text { be applied by patients with or } \\
\text { without supervision. }\end{array}$ \\
\hline $\begin{array}{c}\text { Wang } \\
\text { Z, et al, } \\
(2019) \\
17\end{array}$ & $\begin{array}{l}\text { Relationship of } \\
\text { religiosity to } \\
\text { mental health } \\
\text { literacy, stigma, } \\
\text { social distance, } \\
\text { and occupational } \\
\text { restrictiveness in } \\
\text { Ningxia Province, } \\
\text { China } \\
\end{array}$ & $\begin{array}{l}\text { Annalisa } \\
\text { survey }\end{array}$ & $\begin{array}{l}2.425 \\
\text { participant }\end{array}$ & $\begin{array}{l}\text { Giving } \\
\text { questionnaires for } \\
\text { mental disorders } \\
\text { resilience and } \\
\text { participation in } \\
\text { the spiritual field }\end{array}$ & $\begin{array}{l}\text { The result of the research } \\
\text { states that respondents who } \\
\text { have a good spiritual level } \\
\text { increase the spirit of work, } \\
\text { socialize and also minimize } \\
\text { the occurrence of } \\
\text { psychological disorders such } \\
\text { as stress, unstable emotions } \\
\text { and emotional disorders }\end{array}$ \\
\hline Alshrai & Spirituality, & Cross- & 202 & Giving & This study suggests that the \\
\hline
\end{tabular}




\begin{tabular}{|c|c|c|c|c|c|}
\hline $\begin{array}{c}\text { First } \\
\text { author }\end{array}$ & Title & Design & Sample & Intervention & Result \\
\hline $\begin{array}{l}\text { feen A, } \\
\text { et al, } \\
(2020) \\
\quad 6\end{array}$ & $\begin{array}{l}\text { Anxiety and } \\
\text { Depression } \\
\text { Among People } \\
\text { Receiving } \\
\text { Hemodialysis } \\
\text { Treatment in } \\
\text { Jordan }\end{array}$ & $\begin{array}{l}\text { Sectional } \\
\text { Study }\end{array}$ & samples & $\begin{array}{l}\text { a questionnaire on } \\
\text { the scale of } \\
\text { welfare, spiritualit } \\
y \text {, depression and } \\
\text { anxiety. }\end{array}$ & $\begin{array}{l}\text { rate of spiritual person has } \\
\text { will affect anxiety and } \\
\text { depression. This research } \\
\text { resulted in the conclusion that } \\
\text { respondents whose spiritual } \\
\text { level (praying, thinking } \\
\text { positively, surrendering to } \\
\text { God) would be faster in } \\
\text { coping with depression and } \\
\text { stress. }\end{array}$ \\
\hline $\begin{array}{c}\text { Catarin } \\
\text { a A, et } \\
a l, \\
(2018) \\
18\end{array}$ & $\begin{array}{l}\text { The influence of } \\
\text { spirituality and } \\
\text { religiousness on } \\
\text { suicide risk and } \\
\text { mental health of } \\
\text { patients } \\
\text { undergoing } \\
\text { hemodialysis }\end{array}$ & $\begin{array}{l}\text { Cross- } \\
\text { sectional } \\
\text { study }\end{array}$ & $\begin{array}{l}320 \\
\text { participant } \\
s\end{array}$ & $\begin{array}{l}\text { Examination of } \\
\text { the scale of Faith, } \\
\text { understanding and } \\
\text { belief with a } \\
\text { questionnaire } \\
\text { (FACIT-Sp 12) }\end{array}$ & $\begin{array}{l}\text { This study found that } \\
\text { someone who has a spiritual } \\
\text { solid belief will make suicidal } \\
\text { thoughts, anxiety and } \\
\text { depression levels low. This } \\
\text { means that there is an } \\
\text { effective application of } \\
\text { religion and spirituality in } \\
\text { preventing the occurrence of } \\
\text { ongoing mental disorders. }\end{array}$ \\
\hline $\begin{array}{l}\text { Pandya } \\
\text { SP, et } \\
\text { al, } \\
(2018) \\
19\end{array}$ & $\begin{array}{l}\text { Spiritual } \\
\text { Counseling } \\
\text { Program for } \\
\text { Children with } \\
\text { Anxiety Disorders }\end{array}$ & $\begin{array}{l}\text { A multi- } \\
\text { city } \\
\text { experime } \\
n t\end{array}$ & $\begin{array}{l}1238 \\
\text { sample }\end{array}$ & $\begin{array}{l}\text { Treatment of the } \\
\text { treatment group } \\
\text { with treatment of } \\
\text { mental disorders } \\
\text { combined with } \\
\text { spiritual } \\
\text { counseling }\end{array}$ & $\begin{array}{l}\text { There was a significant } \\
\text { change in the condition of the } \\
\text { treated group with a decrease } \\
\text { in anxiety and depression } \\
\text { levels. }\end{array}$ \\
\hline
\end{tabular}

\section{DISCUSSION}

Religiosity and spirituality are broadly interpreted as patterns of thought, feelings, experiences, behaviors and attitudes that are believed to be the right things in accordance with the social order and group rules, whether human or the needs of the creator 20. Spirituality is not always related to religious behavior such as praying and other worship activities. The spirit here is more inclined towards positive behavior such as confident, enthusiastic, realistic, honest and other good qualities that can positively impact the life process ${ }^{21}$. So that the spiritual position is believed to be able of providing psychological protection to individuals even in unfavorable circumstances ${ }^{22}$.

\section{Impact Spiritual on Mental Health}

This review found that spiritual participation in mental health is fundamental. Motivating with the spiritual approach of religious could reduce trauma and other negative turn into self-trusted, spirit and positive thinking ${ }^{15}$.

Other findings revealed the spiritual impact on mental health that a person who has spiritual solid beliefs will have low levels of suicidal thoughts, anxiety and depression. This means that spiritual beliefs being a foundation of one's thoughts, the bad things will be viewed positively ${ }^{18}$. In addition, individuals who have a spiritual solid level, such as thinking positively, honestly, accepting reality, will make a person feel motivated to socialize, try and be enthusiastic about recovering when he is sick. Because spirituality will make a person have a lighter burden in his feelings and thoughts ${ }^{17}$.

Needed spiritual role in the mental status improvement of a person with a mental disorder, in which the spiritual activities inserted in daily activities can be used as an important aspect in patient's health. The spiritual activities are thought to increase a person's confidence, especially patients with mental disorders. When the confidence arises, patients will be able to increase the immunity ${ }^{23}$.

\section{Models of spiritual healing in mental health}

Many forms of therapy are considered to have a positive impact in the management of mental disorders, as applied in this article: 
SQEFT (Spiritual Qur'anic and Emotional Freedom Technique) is a combination therapy of Al-Qur'an reading and EFT (Emotional Freedom Technique); initially this therapy was used to treat schizophrenic patients, which was later adopted as the scientific development of this therapy. The Islamic State is especially overcoming various mental disorders like depression, stress, anxiety, including violent behaviour. This therapy is effective in reducing mental disorders, but this can only be carried out by individuals who are Muslim and not for individuals of other religions ${ }^{24}$.

SCP (Spiritual Counseling Program) is a program of providing religious counselling. This therapy was aimed at the adolescent population, but it has recently been widely applied at all ages. This therapy is a counselling therapy provided by religious leaders affiliated with schools or counseling service providers that can provide life solutions to achieve a good quality of life, as for the content of the counselling, namely helping to establish a relationship with God. Specs and breathing techniques, concentration of mind, instill and balance of mind and calmness ${ }^{19}$.

\section{CONCLUSION}

Giving spiritual healing both systematically such as SQEFT and SCP therapy, and with a positive behavior reinforcement model will make individuals have calm in thinking and reduce the burden on them. The mental health of patients with mental disorder becomes good. It can be concluded that spiritual healing is effective given to patients with mental disorders as a single therapy or in combination with other therapies.

\section{ACKNOWLEDGMENT}

The author would like to express his deepest gratitude to the Faculty of Nursing, Airlangga University, Surabaya, especially the organizers of the 12th International Nursing Conference in 2021. We also thank all those who helped in the completion of this systematic review

\section{REFERENCE}

1. Sithey G, Li M, Wen LM, Kelly PJ, Clarke K. Socioeconomic, religious, spiritual and health factors associated with symptoms of common mental disorders : a cross- sectional secondary analysis of data from Bhutan' $s$ Gross National Happiness Study, 2015. BMJ. 2018;

2. Koenig HG, Boucher NA, P RJ, Youssef N, Mooney SR, Currier JM, et al. Rationale for Spiritually Oriented Cognitive Processing Therapy for Moral Injury in Active Duty Military and Veterans With Posttraumatic Stress Disorder. The Journal of Nervous and Mental Disease. 2017;205(2):147-53.

3. Charzyńska E, Heszen I. Spirituality and Mental Health Care in a Religiously Homogeneous Country: Definitions, Opinions, and Practices Among Polish Mental Health Professionals. Journal of Religion and Health. 2020;59(1):113-34.

4. Kemenkes RI. InfoDatin Kesehatan Jiwa. Jakarta: Pusdatin Kemenkes RI; 2018. 1-10 p.

5. Nikfarjam M, Solati K, Heidari soureshjani S. Effect of Group Religious Intervention on Spiritual Health and Reduction of Symptoms in Patients with Anxiety. Journal of Clinical and Diagnostic Research. 2018;12(10):6-9.

6. Alshraifeen A, Alnuaimi K, Al S, Ala R. Spirituality, Anxiety and Depression Among People Receiving Hemodialysis Treatment in Jordan: Journal of Religion and Health. 2020;(0123456789).

7. Dein S. Against the Stream: religion and mental health - the case for the inclusion of religion and spirituality into psychiatric care. BJPsych Bulletin. 2018;42:127-9.

8. Jones S, Sutton K, Isaacs A. Concepts , Practices and Advantages of Spirituality Among People with a Chronic Mental Illness in Melbourne. Journal of Religion and Health. 2018;

9. Moher, Liberati, J. Tetzlaff A. PRISMA 2009 Checklist. Annals of Internal Medicine. 2014;151:264-9.

10. Mara É, Pereira L, Marcelo J, Alves J, Junior $\mathrm{T}$, Jacinto C, et al. Complementary Therapies in Medicine Effectiveness of Spiritist “ passe " ( Spiritual healing ) for anxiety levels, depression, pain, muscle tension, well-being , and physiological parameters in cardiovascular inpatients: A randomized controlled. Complementary Therapies in Medicine. 2017;30:73-8.

11. Chida Y, Schrempft S, Steptoe A. A Novel Religious / Spiritual Group Psychotherapy Reduces Depressive Symptoms in a Randomized Clinical. Journal of Religion and Health. 2016;55(5):1495-506.

12. Sankhe A, Dalal K, Save D, Sarve P. Evaluation of the effect of Spiritual care on patients with generalized anxiety and depression: a randomized controlled study. Psychology, Health \& Medicine. 2017;0. 
13. Silva J, M A. Perceived Spirituality , Mindfulness and Quality of Life in Psychiatric Patients. Journal of Religion and Health. 2017;56:130-40.

14. Serfaty DR, Cherniak AD, Strous RD. How are psychotic symptoms and treatment factors affected by religion? A cross-sectional study about religious coping among ultra-Orthodox Jews. Psychiatry Research. 2020;113349.

15. Harris JI, Usset T, Voecks C, Thuras P, Currier J, Erbes C. Spiritually integrated care for PTSD : A randomized controlled trial of “ Building Spiritual Strength ." Psychiatry Research. 2018;267(December 2017):420-8.

16. Rosyanti L, Hadi I, Islam AA, Hasanuddin U, Natzir R, Hasanuddin U. Change of Brief Psychiatric Rating Scale ( BPRS ) Value with Spiritual Qur' anic Emotional Freedom Technique ( SQEFT ) Therapy on Mental Disorder Patient CHANGE OF BRIEF PSYCHIATRIC RATING SCALE ( BPRS ) VALUE WITH SPIRITUAL QU R' ANIC EMOTIONAL FREEDOM. Journal of Public Health Research and Development. 2019;(January).

17. Wang Z, Chen H, Koenig H, Phillips MR, Wang Z, Chen $\mathrm{H}$, et al. Relationship of religiosity to mental health literacy, stigma , social distance, and occupational restrictiveness in Ningxia Province, China. Mental Health, Religion \& Culture. 2019;4676.

18. Catarina A, Loureiro T, Carlota M, Coelho DR, Bigesca F, Henrique L, et al. The influence of spirituality and religiousness on suicide risk and mental health of patients undergoing hemodialysis. Comprehensive Psychiatry. 2018;80:39-45.

19. Pandya SP. Spiritual Counseling Program For Children with Anxiety Disorders: A multicity experiment. Journal of Pastoral Care \& Counseling. 2018;72(1):45-57.

20. Koenig HG, Pearce MJ, Nelson B, Sally F, Robins CJ, Daher NS, et al. Religious vs . Conventional Cognitive Behavioral Therapy for Major Depression in Persons With Chronic Medical Illness. The Journal ofNervous and Mental Disease. 2015;203(4):243-51.

21. Park CL, Smith PH, Lee SY, Mazure CM, Mckee SA, Park CL, et al. Psychology of Religion and Spirituality Positive and Negative Religious / Spiritual Coping and Combat Exposure as Predictors of Posttraumatic Stress and Perceived Growth in Iraq and Afghanistan Veterans Positive and Negative Religious / Spiritual Coping a. 2016;

22. Abdaleati NS, Zaharim NM, Mydin YO. Religiousness and Mental Health : Systematic Review. 2014;

23. Pearce M, Haynes K, Rivera NR, Koenig HG.
Spiritually Integrated Cognitive Processing Therapy: A New Treatment for Posttraumatic Stress Disorder That Targets Moral Injury. Global Advances in Health and Medicine. 2018;7:1-7.

24. Rosyanti L, Hadi I, Tanra J, Islam A, Hatta M. The Effectiveness of Spiritual Qur ' anic Emotional Freedom Technique ( SQEFT ) Intervence Against the Change of Brief Psychiatric Rating Scale ( BPRS ) on Patient with Schizophrenia. Health Notions. 2018;2(8):895-900. 